\title{
Changing Paradigms in US and EU Supply Chains: Focusing on Sustainability Issues
}

Author(s): Hyo-young Lee

Source: Journal of International Logistics and Trade 2021; 19(4):223-236

Published by: Jungseok Research Institute of International Logistics and Trade, Inha University

DOI: https://doi.org/10.24006/jilt.2021.19.4.223

Journal of International Logistics and Trade is an official journal published by Jungseok Research Institute of International Logistics and Trade, Inha University, Korea. JILT welcomes manuscripts that advance the practice and science of logistics, trade, and other related fields.

Frequency: Quarterly (March, June, September, December)

Stable URL: https://www.ejilt.org

Jungseok Research Institute of International Logistics and Trade is a specialized academic research institute representing Inha University and Inha Foundation in Korea. The institute aims to become a representative institute in Northeast Asia in the research of logistics and trade.

Stable URL: https://jrieng.inha.ac.kr

(C) Copyright. Jungseok Research Institute of International Logistics and Trade.

This is an Open-Access article distributed under the terms of the Creative Commons Attribution NonCommercial License (http://creativecommons.org/licenses/by-nc/4.0/) which permits unrestricted noncommercial use, distribution, and reproduction in any medium, provided the original work is properly cited 



\title{
ARTICLE
}

\section{Changing Paradigms in US and EU Supply Chains: Focusing on Sustainability Issues}

\author{
Hyo-young Lee \\ Korea National Diplomatic Academy, Seoul 06750, Korea
}

Received November 21, 2021
Revised December 5, 2021
Accepted December 9, 2021

*Corresponding author: Hyo-young Lee
Korea National Diplomatic Academy, Seoul
06750, Korea
Tel: +82-2-3497-7651
E-mail: hylee17@mofa.go.kr

Received November 21, 2021

Revised December 5, 202

E-mail: hylee17@mofa.go.kr

\begin{abstract}
In the aftermath of the COVID-19 pandemic, supply chains have become important policy tools to ensure the security and resilience of regional trading blocs of major economies. The US government's focus on supply chains for selected strategic industries and the EU Commission's renewed efforts to strengthen its supply chains using 'sustainability standards' coincides with the global trend in the shift towards digital and lowcarbon economies. Furthermore, the rising tensions between the US and China, with no signs of reconciliation over key issues of contention, have emphasized the need for more credibility and trust in global supply chains. However, such policies also have the potential to serve as new barriers to participation in supply chains by less-developed economies which are not yet prepared to meet the high-level sustainability criteria which aim for higher protection of the environment and labor rights. There also seems to be an apparent shift in paradigm supporting the interventionist role of government that emphasize the need for more discretion for policy objectives that pursue societal and democratic values, not to mention national security interests. The current rules of international trade, however, do not sufficiently address these new issues and need to be realigned in order to meet the new demands. The current 'rules of the game' need to be reinforced in order to accommodate the rising need of countries for increased consideration of issues of sustainability and competitiveness.
\end{abstract}

Keywords Supply chain, Environment, Labor, Sustainability, Industrial policy

\section{Introduction}

The consistent growth and expansion of global supply chains that has led global trade growth during the past 30 years has been weakening since the global financial crisis in 2008-09 (WTO 2019a). More recently, structural changes in global supply chains have become more prominent due to the shifting role of China in global value chains (GVC) and the increasing trends of re-shoring or near-shoring of production sites to different strategic locations along the global supply chain. China has enjoyed its position as a production hub in Asian regional supply chains since the 2010s, leading to significant growth in trade and economic development which has enabled the country to climb up the supply chain ladder to engage in higher value-added activities by its domestic industries. As China's industrial structure became more sophisticated, the higher was the value-added of China's production activities in the value chain, thus also leading to higher dependence of the developed economies (such as the US, EU) on GVC-based trade with China and other emerging developing economies in the Asian regional supply chain (ADB 2021).

Since the US Biden Administration came into office, there have been aggressive efforts to reform the existing supply chains which have been highly dependent on China as an efficient location of production activities for the global trade of intermediate goods. The US government's focus on the supply chains for selected products (semiconductors, batteries for electric vehicles, critical minerals, and medical supplies) officially comes in the wake of the COVID-19 pandemic and recent semiconductor shortages, but there are more fundamental issues underlying the policy change. The rising tensions between the US and China, with no signs of reconciliation regarding the key issues of contention, have placed spotlight on the need for more credibility and trust in global supply chains, which has led to placing emphasis on democratic systems with due considerations for labor and human rights. The renewed policy on global supply chains also coincides with the global trend in the shift towards digital and low-carbon economies, leading to policies that can serve as potential barriers to participation in supply chains by lessdeveloped economies which are not yet prepared to meet the high-level privacy protection or environmental protection criteria. 
The new EU Commission led by President Von der Leyen, which came into office in December 2019, has been pursuing new strategies to prepare the regional economic bloc to become more sustainable and competitive in responding to the challenges of digitalization and climate change. One of the policy tools that have been contemplated by the EU also involves supply chains, by putting in place new legislations that mandate both EU and non-EU companies to meet 'sustainability standards' as part of due diligence requirements in order to participate in EU supply chains (European Commission 2020).

These prominent changes in supply chain policies initiated by leading global economies and regional blocs can be considered to be tantamount to a 'paradigm shift' from the decades-long focus on 'efficiency' in GVC activities in favor of greater supply chain 'resilience'. No longer is the market-oriented approach based on efficiency principles the 'rules of the game' regarding supply chains, with calls for the increased role of government in managing supply chains with due consideration of national security concerns and efforts to tackle the global issues of climate change and human rights. While 'sustainability' has risen as the new key word for enhancing the resilience of supply chains, the underlying motive behind the new policy directions appears to be a renewed strategy for establishing a 'level playing field' for developed economies that have been bearing the costs of decarbonisation which have weakened their competitive edge vis-à-vis the less-developed economies with lower standards of environment protection.

Against this background, this paper aims to look into the supply chain reform initiatives pursued by the US and EU, and identify the main drivers and motives behind the 'paradigm shift' in their global supply chain policies. While 'sustainability' and 'resilience' may sound neutral in its purpose, these initiatives are accompanied by large-scale industrial policies that aim to enhance the industrial competitiveness of these economies in key strategic areas to meet the demands of the future economy. The current international trade rules, however, are not envisaged to support the interventionist role of government and places emphasis on less-restrictive trade policies that are proportional to the policy objectives of environmental protection or other legitimate policy objectives. Therefore, the policies to strengthen supply chain resilience, if implemented without careful coordination and consideration of the fundamental objectives served by international trade rules, may result in protectionist outcomes that lack legitimacy and support by other countries participating in the global supply chain. As a consequence, the current 'rules of the game' may also need to be reinforced in order to accommodate the rising need of countries for increased consideration of issues related to climate change and sustainability.

The remainder of the paper is structure as follows: Section 2 and 3 outlines the policy direction of the US and EU for enhancing supply chain resilience, and the main policy tools used to implement the policy objective. Section 4 looks into the current WTO rules that govern the related policy issues such as subsidies, non-discrimination, and the general exceptions clause that allow for Member countries to pursue policies for legitimate purposes, in order to identify areas where the policies for supply chain resilience and current trade rules do not align. Section 5 concludes with a brief note on prospects for the international economic order.

\section{US policies to strengthen supply chain resilience}

\subsection{US policies for supply chain resilience}

Since its inauguration in January 2021, the Biden administration has promised to bring the production capabilities in economically and technologically sensitive sectors back to the US under the slogan 'Build Back Better'. In line with this policy direction, the US government is working to build stronger supply chains and revitalize domestic manufacturing, and affirmed its desire to 'work with US allies and partners to strengthen collective supply chain resilience' (The White House 2021).

On June 8, 2021, the Biden administration released the findings of its 100-day review of US supply chain vulnerabilities mandated under President Biden's Executive Order 14017 that was issued in February. Four federal agencies (Department of Commerce, Energy, Defense, and Health and Human Services) provided their analysis and recommendations as a result of their assessment of supply chain vulnerabilities in the four critical sectors (semiconductor manufacturing and advanced packaging, large capacity batteries, critical minerals and materials, pharmaceutical and advanced pharmaceutical ingredients). According to the White House, strengthening US supply chains into more secure and resilient ones is "essential for our national security, economic security, and our technology leadership".

In terms of national security, the US perceives its underlying commercial industrial foundations to be central to its security, which in turn raises concerns about the US defense industry's reliance on limited domestic suppliers and the vulnerability of global supply chains to disruptions (i.e., natural disasters, disease outbreaks such as the COVID-19 pandemic). The US alleges that it currently lacks innovative capacities which are essential to its military preparedness, and calls for the establishment of 
an ecosystem of innovation, skills and production facilities.

Secure and resilient supply chains are also required for 'economic security', which according to the US, refers to the steady employment and smooth operation of critical industries. For example, the supply of strategic and critical materials, such as lithium and cobalt (core inputs to high-capacity batteries which are used in electric vehicles), is highly dependent on China, revealing a critical vulnerability to the future of the US automobiles industry.

Technology leadership of the US, which allegedly depends on its domestic innovation capacity, is contingent on a robust and diversified industrial base. However, the geographic concentration of semiconductors fabrication in several countries in Asia can result in significant disruption across the supply chain, susceptible to risks caused from natural or human-made disasters and geopolitical tensions as well. More importantly, the US perceives its lack of public investment in semiconductor fabrication to have allowed foreign companies to outpace the competitiveness of US firms. Therefore, it is recommended that the lack of domestic capacity needs to be reinforced by large-scale investments in new fabrication facilities in the US with the cooperation of leading foreign companies in chip fabrication that are based in allied countries with the US.

As revealed through the 100-day Review Report, the US government identifies a number of vulnerabilities in its current supply chains for the selected sectors. The semiconductor and high-capacity battery industries, which represent the key innovative technology sectors that are critical for future economic activities, place emphasis on the need for enhanced domestic manufacturing capacity that are less reliant on foreign sources of supply. The reports also call for a strengthened domestic industrial base for the sustainable production of these products, through support for demand policies, investment incentives and regulatory measures to stimulate domestic production. Citing reasons of 'market failure', such as the lack of investment by private companies in key strategic products and sectors, the US government appears to be setting the stage for the use of 'industrial policies' that have been actively pursued by other countries, namely EU, Taiwan, Korea, Singapore, and China (The White House 2021).

As for critical minerals and materials, the sector has been identified as a critical area for meeting the demands of decarbonisation, as the demand for many of the rare earth metals (i.e., lithium and graphite) are projected to grow prominently in order to achieve climate goals. However, unlike the other sectors, achieving the security and resilience of the minerals supply chain is closely linked to the labor and environmental standards pursued by the US Since low environmental and labor standards undermine the competitive edge of US-manufactured products, the US government calls for the creation of ' $21^{\text {st }}$ century standards' for the extraction and processing of critical minerals by developing and adopting comprehensive 'sustainability standards' for essential minerals (i.e., lithium, cobalt, nickel, copper and other minerals). The Biden Administration also plans to use its 'Made in America' provisions to establish a list of designated critical products that will receive additional preferences in order to ensure that the federal government procures US-made critical products.

\subsection{Other US policies to promote industrial competitiveness}

In line with the supply chain resilience initiatives, the US government has been aggressively pursuing legislative efforts to provide large-scale investment in the strategic sectors which it has identified through its supply chain review report. President Biden's Executive Order on 'Made in All of America' (E.O. 14005), issued one month prior to the Executive Order on America's Supply Chains, calls for the legislation of 'Buy America' regulations that require or provide a preference for the purchase of products or materials produced in the US, including iron, steel and other manufactured goods. Once implemented, the 'Made in America' regulations will be equipped with stronger implementation measures compared to the Buy America Act of 1933, with increased numerical thresholds for domestic content requirements and increased price preferences for domestic end products and construction materials. Furthermore, tests to verify 'American made' will be measured by the value that is added to the product through US-based production or US job-supporting economic activity. Coupled with the 'Buy American' policy, the Biden Administration's 're-shoring' or supply chain resilience initiative is expected to have a significant impact on providing renewed opportunities for US domestic industries to enhance their manufacturing capabilities and competitiveness.

The Biden Administration also announced a series of large-scale investment plans to modernize its overall economic infrastructure and its semiconductor manufacturing capacities in particular. In March, President Biden announced the 'America Jobs Plan', which aims to provide 2.2 trillion USD in public investments to modernize its transportation, public utilities, telecommunications, innovative technology, manufacturing, education, health, and housing sectors. The American Innovation and Competition Act (AICA), the legislation for providing 250 billion USD of public investments in semiconductor manufacturing, R\&D in science and innovation technology, AI, space exploration etc., passed the US Senate in June. The Chips for America Act and the American Foundries Act, which are included in the AICA legislation package, will provide 52.7 billion 
USD in public investment for building US domestic capacity in semiconductor manufacturing.

As observed so far, despite the emphasis on resilience and sustainability of global supply chains, the various policy measures that accompany the US government's efforts to strengthen its supply chains reveal its underlying motive of revitalizing its domestic manufacturing sector so that it regains its former superior economic position to maintain its hegemonic position in the international political and economic order. The US preference for 'Buy American' stands out prominently among the policy measures as it reveals the possible protectionist or discriminatory impact, especially when the supply chain initiatives and reshoring policies are implemented together with the Made in All of America procurement measures. The Buy America and reshoring policies may ultimately make achieving greater supply chain resilience more difficult and more expensive in the long run. This is because one of the best ways to promote resilience would be to diversify the sources of supply, while some of the proposed recommendations appear to run counter to it (CSIS 2021). Also, while there is heated debate and confused approaches regarding whether to abandon 'efficiency' and pursue 'resilience' in managing supply chains, there may be a false dichotomy between the two objectives. As the objectives of efficiency and resilience are not mutually exclusive, both actually need to be maintained for companies to survive in the long term (Gölgeci et al. 2020). Furthermore, the incentives for allies to work with the US to secure supplies of critical minerals or to make investments in semiconductor production facilities could be undermined by the US preference for 'Buy American' if implemented without appropriate waivers for allies and partners.

\section{EU policies to strengthen supply chain resilience}

\subsection{EU's trade strategy and approach to China}

As EU-China relations have been increasingly strained in recent years, there have been conflicting approaches toward China within the EU, also based on its insecurities about its own future economic position in the world. Increasing tensions between the US and China have also become an issue of contention in the transatlantic relationship, despite the fact that EU has also had frustrations about China and its political and economic practices.

In response to the challenges posed by China and the US unilateral trade policies under the Trump Administration, EU has announced its position to pursue 'strategic autonomy', implying that it aims to be a neutral third pillar in a world order which is being muddled by the tensions between the US and China. While the new US Administration places greater importance on cooperation with its allied partners, especially with its European counterparts, the US and EU actually have fundamentally different views and positions on several issues. This includes not only whether to take a confrontational or mainly defensive approach to China, but also various important issues related to digital trade and the future of the multilateral trading system as a whole. Furthermore, even on policy areas which the transatlantic countries share views and objectives, the approach taken by the respective countries appear to be quite different (European Commission 2019). In fact, EU's choice of policy measures appears to be more seemingly neutral and non-discriminatory than the unilateral and more explicit approach of the US in pursuing its policy objectives. However, the underlying motives of EU may not be that different in the current post-pandemic world, where securing resilient supply chains and strengthening domestic industrial competitiveness in key strategic sectors are imminent tasks for all sovereign countries around the world.

The new EU Commission headed by President von der Leyen, which came into office in December 2019, has been pursuing policy responses to 'climate change' and 'digital transformation' as key priorities for EU's long-term sustainable growth. These policy priorities have also been major pillars of EU's 'Industrial Policy Strategy' (adopted in May 2019 under President Juncker) with aims to empower European industries to continue delivering sustainable growth and jobs through emphasis on "innovation, digitization and decarbonisation" (Council of the European Union 2019). Under the von der Leyen Commission, EU has announced the 'European Green Deal' as a roadmap for EU to achieve climate-neutrality by 2050 and its digital strategy 'Shaping Europe's Digital Future' to pursue a digital transition that works for both the people and businesses and to use digital solutions to achieve green transition.

In its communication on 'An Open, Sustainable and Assertive Trade Policy' (European Commission 2021), EU asserts the pursuit of an 'Open Strategic Autonomy' under which EU would enhance its "ability to make its own choices and shape the world around it through leadership and engagement, reflecting its strategic interests and values". To this end, EU emphasizes the importance of open and fair trade with "well-functioning, diversified and sustainable global value chains". In particular, EU acknowledges that vulnerabilities in the 'resilience' of supply chains, especially in the case of supply disruptions or demand shocks, are revealed when companies depend on a single supplier and concentrated production. Therefore, it emphasizes that trade policy can contribute to enhancing supply chain resilience by providing a stable, rules-based trading framework, and by 
opening up new markets to diversify sources of supply. Furthermore, EU calls attention to its policy emphasis on 'sustainability', by stating that enhancing the resilience of supply chains comes in parallel with the EU's objective of making supply chains more sustainable.

EU has also announced its policy to pursue 'sustainable corporate governance' (European Parliament 2020) under the goal to promote more environment-friendly and responsible commercial activities on the part of firms operating within the EU market. The policy is based on EU's recognition that the existing 'voluntary' international initiatives promoting sustainable corporate governance have been largely ineffective in ensuring compliance with the sustainability approach to corporate governance since they have been mainly based on instruments of 'soft law'. Therefore, there is a need to adopt a legislative framework for European companies to ensure compliance with and improve legal certainty in the internal market and not create competitive disadvantages. Thus 'corporate responsibility' refers to the legal requirement to disclose information related to environment, social and employee issues and human rights, bribery and corruption as defined in the UN Guiding Principles on Business and Human Rights. Furthermore, the Report mentions that in order to make corporate governance more sustainable, transparent and accountable, new legislation on 'due diligence' and directors' duties should be introduced, and in order to provide a 'level playing field', the obligations should also apply to non-EU companies operating in the EU market. Finally, the Report pinpoints that the COVID-19 pandemic, which has exposed the vulnerabilities of global supply chains, has shown that voluntary rules alone are not enough, and that businesses with better defined environmental, social and governance practices have weathered the crisis better.

As can be observed so far, supply chain resilience is closely linked to the renewed focus on 'industrial policy' for Europe. EU's 'New Industrial Strategy for Europe' (released in October 2020), emphasizes the need to increase supply chain resilience and calls for 'smart reshoring' by relocating industrial production in sectors of strategic importance for EU. The strategic sectors refer to critical raw materials, pharmaceuticals and API, and semiconductors. It is also part of this initiative that progress has been made in efforts to strengthen mandatory due diligence requirements for EU companies concerning human rights and environmental considerations in global supply chains (Bergsen 2021).

\subsection{EU policies for supply chain resilience}

In terms of its supply chain policy, the EU has announced legislative plans in April 2021 to mandate the due diligence requirements for firms participating in EU supply chains based on 'sustainability standards'. According to the 'Resolution on Corporate Due Diligence and Corporate Accountability' announced in March 2021 by the European Parliament, EU perceives that due to the globalization of economic activities, the negative impact of business activities on human rights (including social and labor rights), environment, and good governance of states have been aggravated, and that human rights violations occur more often in production activities for sourcing raw materials and manufacturing products. However, if due diligence were to be implemented more comprehensively, companies will be able to focus on prevention of such adverse impact from occurring in the first place, rather than remediating harms, which would also provide long-term benefits for companies from better business conduct (Council of the European Union 2020).

EU acknowledges that the legislation on corporate due diligence and corporate accountability would have extraterritorial effects, and therefore, would affect the social, economic and environmental development of developing countries that would help them achieve their sustainable development goals (SDGs). According to the Report, corruption and lack of transparency greatly undermine human rights, by preventing individuals from accessing goods and services obligations (i.e., by increasing the price of such goods and services) that States are obliged to provide to meet their human rights. In particular, climate change can have adverse impact on the full and effective enjoyment of human rights, while forced labor is a matter of fundamental human rights since it involves not only the exploitation and degradation of human through forced labor, but the denial of access to the right to form and join trade unions, the right to collective bargaining and action, as well as the right to fair remuneration and decent working conditions which all undermine basic human rights.

EU considers that voluntary methods of implementing due diligence have had limitations and not achieved significant progress in preventing human rights and environmental harm. Therefore, it follows that the Union should adopt binding requirements that would make companies identify, prevent, mitigate, account for, and remediate potential and actual adverse impacts on human rights, the environment and good governance in their value chains. EU believes that this would be beneficial for businesses in terms of leveling the playing field for EU companies and for mitigating unfair competitive advantages enjoyed by third countries, resulting from lower protection standards as well as social and environmental dumping in international trade. EU expects that by making the due diligence requirement by companies mandatory, the transparency and certainty of corporate 
practices in procuring raw materials and manufactured products from third countries can be enhanced, while also enhancing consumers' trust, and contributing to establishing long-term business relationships through more responsible purchasing practices within the supply chains.

Once implemented, the due diligence obligations would be applied as a condition to entering the EU market, by requiring the operators to establish and provide evidence, through the exercise of due diligence, that the products they place on the EU market are in conformity with the environmental and human rights criteria set out in the due diligence legislation. In order to ensure effectiveness, the scope of the mandatory due diligence framework has been set broadly to cover all large corporations regardless of sector, as well as publicly listed small and medium-sized enterprises (SMEs) and SMEs that operate in high-risk sectors. Most importantly, if a company concludes that it does not cause or contribute to any potential or actual adverse impact on human rights, the environment or good governance, it is obligated to publish a 'statement' which includes 'risk assessment' containing the relevant data, information and methodology used to reaching such a conclusion. The risk assessment must cover the due diligence performance of all the direct suppliers and subsidiaries. However, if the corporation is unable to conclude as such, it has to establish and implement a 'due diligence strategy', which specifies the potential or actual adverse impacts and the level of severity of the impact based on relevant data and methodology, and identifies all proportionate policies and measures to cease, prevent or mitigate the adverse impact on human rights, the environment or good governance.

As a means to ensure effective implementation, the directives would allow the competent authorities of EU member states to have the power to carry out investigations to ensure that corporations comply with the obligations. Investigations have to be conducted on a risk-based approach, even allowing for investigations to be initiated based on suspected breach, including on the basis of substantial and reasonable concerns raised by any third party. Furthermore, if the failure to comply with the directives could lead to irreparable harm, temporary suspension of activities may be ordered, or even impose a ban on operating

Table 1. Summary of US and EU approaches for strengthening supply chain resilience

\begin{tabular}{|c|c|c|}
\hline & US approach & EU approach \\
\hline Objective & $\begin{array}{l}\text { Build stronger supply chains that are not dependent on } \\
\text { concentrated sources of supply, and revitalize domestic } \\
\text { manufacturing industries. }\end{array}$ & $\begin{array}{l}\text { Pursue 'strategic autonomy' amid rising US-China } \\
\text { tensions, and resolve insecurities about EU's future global } \\
\text { economic position. }\end{array}$ \\
\hline Rationale & $\begin{array}{l}\text { Essential for national security, economic security, and } \\
\text { technology leadership. }\end{array}$ & $\begin{array}{l}\text { Responding to climate change and digital transformation } \\
\text { as key priorities for EU's long-term sustainable growth. }\end{array}$ \\
\hline \multirow[t]{4}{*}{ Key policies } & $\begin{array}{l}\text { Addressing supply chain vulnerabilities in critical sectors. } \\
\text { - Semiconductor manufacturing, batteries for electric } \\
\text { vehicles, critical minerals for IT products, pharmaceutical } \\
\text { products. }\end{array}$ & $\begin{array}{l}\text { 'Open, Sustainable and Assertive Trade Policy' } \\
\text { - Open and fair trade with well-functioning, diversified } \\
\text { and sustainable global value chains. }\end{array}$ \\
\hline & $\begin{array}{l}\text { 'Made in All of America' regulations } \\
\text { - Strengthened domestic content requirements and price } \\
\text { preference for US made products and materials. }\end{array}$ & $\begin{array}{l}\text { 'Sustainable Corporate Governance' } \\
\text { - More environment-friendly and responsible commercial } \\
\text { activities by firms operating in EU market. }\end{array}$ \\
\hline & $\begin{array}{l}\text { 'America Jobs Plan' } \\
\text { - Large-scale investments for modernization of public } \\
\text { infrastructure (transportation, public utilities, } \\
\text { telecommunications, etc.). }\end{array}$ & $\begin{array}{l}\text { 'New Industrial Strategy for Europe' } \\
\text { - Emphasis on need to increase supply chain resilience } \\
\text { and 'smart reshoring' by relocating industrial production } \\
\text { sites in sectors of strategic importance. }\end{array}$ \\
\hline & $\begin{array}{l}\text { 'America Innovation and Competition Act' } \\
\text { - Large-scale public investments in semiconductor } \\
\text { manufacturing, R\&D in science and innovation technologies, } \\
\text { etc. }\end{array}$ & $\begin{array}{l}\text { Mandatory due diligence requirement for EU and non-EU } \\
\text { firms participating in EU supply chains } \\
\text { - Use of 'sustainability standards' (environment, } \\
\text { labor/human rights criteria) as condition to entering EU } \\
\text { market. }\end{array}$ \\
\hline Policy motives & $\begin{array}{l}\text { Revitalize domestic manufacturing sector and regain former } \\
\text { economic position to maintain hegemonic position in } \\
\text { international order. }\end{array}$ & $\begin{array}{l}\text { Level playing field for EU companies and mitigate unfair } \\
\text { competitive advantages enjoyed by third countries with } \\
\text { lower protection standards }\end{array}$ \\
\hline Limitations & $\begin{array}{l}\text { - Possible protectionist or discriminatory impact. } \\
\text { - Strengthened Buy America provisions may undermine } \\
\text { achieving supply chain resilience in long-term. } \\
\text { - False dichotomy between 'efficiency' and 'resilience' } \\
\text { in supply chains. } \\
\text { - Need incentives for foreign allies and partners to join US } \\
\text { supply chain resilience initiative. }\end{array}$ & $\begin{array}{l}\text { - Seemingly neutral and non-discriminatory, but with } \\
\text { similar protectionist motives as US policy for supply } \\
\text { chain resilience. } \\
\text { - Mandatory obligations for participation in EU supply } \\
\text { chain are not in line with the principle of 'proportionality' } \\
\text { as the appropriate level of policy response to expected } \\
\text { risk or size of problem. }\end{array}$ \\
\hline
\end{tabular}


in the internal market. Also, EU member states may impose sanctions against corporations that do not take remedial action through the imposition of administrative fines.

Initial plans to propose legislation by the first half of 2021 on mandatory due diligence are being delayed, while there is unwelcome reaction by EU corporations regarding the new obligations. Questions are being raised about the workability of the directive, since it would require companies like Airbus with more than 12,000 suppliers worldwide, and Carrefour with supermarkets that stock up to 80,000 products, to oversee their entire supply chain. The expansive scope of application (extraterritorial) which makes the legislation have global impact, in addition to the burdensome mandatory obligations for due diligence, could lead to regulatory overreach into complex global supply chains that could result in poor practical implementation (Beghin and Vermulst 2021). It is also unclear how the EU authorities would differentiate between the various degrees of relationships within supply chains. While the definition of 'business relationships' is narrowed down to those only having a 'direct' link to a company's business operations, companies are still obliged to 'map their value chain', which includes all entities with direct or indirect business relationships. Furthermore, with more heavy liability rules for non-compliance, parent companies could be held more liable for harms caused by subsidiaries in third countries. Companies from third countries that have business relationships with European companies, on the other hand, will be burdened by the new requirement to provide due diligence reports on human rights, labor, and environment protection on their own part, regardless of their technical capacity to provide credible assessments. A summary of the US and EU approaches is provided in Table 1 above.

\section{Assessing policies for achieving supply chain resilience and international trade rules}

There are various public policy tools that can assist governments in fostering supply chain resilience with different implications on trade and international cooperation. First, it should be noted that firms are the principal actors in the efforts to increase supply chain resilience. However, governments also play a key role by encouraging or restraining the sourcing decisions for supply chains at the national level. Therefore, strengthening public-private coordination to achieve supply chain resilience would be an important task for attaining actual results and successful outcome.

There appears to be a mix of policy objectives that are intertwined in the supply chain resilience initiatives with different implications as well. According to Schneider-Petsinger (2021), there are various government motives behind the supply chain resilience policies, since they also serve the broader economic, societal and strategic rationales for strengthening supply chains at both the national and international levels. Such government motives include: (1) addressing market failures in supply chains; (2) enhancing crisis preparedness and response regarding health and personal safety; (3) strengthening national security; (4) boosting industrial strength and economic competitiveness; (5) creating domestic jobs; (6) promoting human rights and sustainability.

Policy responses that seek to balance between rights and public interests in decision-making should be guided by the principle of 'proportionality', which is a legal doctrine for determining to what extent individual rights can be limited for the sake of the promotion of public interests. When applied more broadly, the proportionality principle can provide guidance on the appropriate level of policy response to social rights-related issues, under which the objective or impact of a policy measure should best be proportionate to the level of the expected risk or size of the problem.

Therefore, an evaluation of the supply chain reform initiatives pursued by the US and EU leads to a preliminary conclusion that too many objectives may have been incorporated into the policy tool box for enhancing supply chain resilience. According to Schneider-Petsinger (2021), the public policy objectives related to the supply chain initiatives can be categorized into three categories: (1) 'restrictive' (strategic policies that seek to limit investment and trade, i.e., tariffs, export controls); (2) 'encouraging' (i.e., tax concessions or subsidies to promote domestic investment); and (3) 'cooperative' (policies that create conducive business environment that allow strategic sectors to flourish, i.e., measures that support national infrastructure). In particular, restrictive policy measures that discriminate against foreign suppliers, including those from allied and partner countries, may result in offsetting the policy measures that are 'encouraging' and 'cooperative'. Therefore, implementation of the various policy recommendations for achieving the objective of stronger resilience in supply chains need to consider whether they can be justified from the existing international trade rules which serve the fundamental principles of non-discrimination and limit disproportionate trade-restrictiveness. The following sub-sections look into several specific aspects of the supply chain policy measures with a view to evaluate the legitimacy of the measures under relevant WTO rules.

\subsection{WTO rules on non-discrimination}

Non-discrimination is a key concept in WTO rules, comprised of the most-favored-nation (MFN) treatment obligation and 
the national treatment obligation. In simple terms, the MFN treatment obligation prohibits countries from discriminating 'between' other countries, while the national treatment obligation does not allow countries to discriminate 'against' other countries (Van den Bossche and Zdouc 2013). Many protectionist trade policies discriminate against other countries by providing preference to domestic suppliers and manufacturers, or discriminate between other countries based on their preferential bilateral relationships or trade arrangements. Therefore, providing for non-discrimination is an important key principle in international trade that allows countries to benefit from trade regardless of their political economic relationships or position in the world market, but based on their competitiveness of the goods and services that are produced and sold in the international market.

Article 1 of the General Agreement on Tariffs and Trade (GATT) 1994 and Article II of the General Agreement on Trade in Services (GATS) provides for the MFN obligation, which prohibits discrimination against 'like products' and 'like services' on the basis of the national origin of a product or a service. Basically, a 'four-tiered test' is applied to evaluate whether a policy measure is in violation of the GATT Article 1 MFN treatment obligation, by looking into whether the measure at issue falls under the scope of application of the provision, whether the measure at issue confers a trade 'advantage', whether the products concerned are 'like products', and whether the advantage at issue is granted 'immediately and unconditionally' to all like products concerned.

As regards the first requirement, policy measures that are implemented both within the border (domestic regulations) and on the border (border measures) are covered under Article 1. With regard to the second requirement, a measure would confer an advantage if it 'modifies the conditions of competition' in favor of the domestic producer or supplier compared to the like product or services supplier of any other WTO member country. Furthermore, the non-discrimination treatment obligations include both de jure and de facto discrimination, meaning that even if the policy measure at issue appears to be neutral in its application based on nationality of the product or service, it would be a violation if the applied measure results in discriminating disproportionately against the foreign product or service. As for 'like products' or 'like services', a number of Panel and Appellate Body rulings have followed the practice of considering the end-use of the product, consumers' tastes and habits, characteristics (properties, nature and quality) of the product, and tariff classifications for determining whether the products concerned are 'like' or not. It has been a subject of debate regarding whether the method of production or processing of a product (PPM) is relevant in determining whether products are 'like'. However, the prevailing jurisprudence is that non-product related processes and production methods (NPR PPMs) are not relevant, implying that products that are produced in an environmentally unfriendly manner cannot be justified for discriminatory treatment. Furthermore, the obligation for national treatment obligation which applies to 'directly competitive or substitutable products' as well implies a broad application of the non-discrimination obligation in order to prohibit trade practices that have detrimental impact on products that are in a competitive relationship in the market. Lastly, the requirement to grant advantages 'immediately and unconditionally' to all products from any country means that a Member cannot make the granting of that advantage to imports of other Members conditional on those advantages that the other Members give in return. Therefore, the granting of an advantage cannot be conditional on whether a Member has certain characteristics, or has certain legislations in place, or undertakes a certain action (Van den Bossche and Zdouc 2013).

Based on these criteria, the due diligence obligations to be imposed by EU as a condition for entering the EU market can be considered to be a violation of WTO rules on non-discrimination even if the scope of application extends to all corporations regardless of nationality. The 'sustainability standards' that are to be used for determining whether a supplier has met the environmental or labor protection levels needed for entry into the EU market are implicitly discriminatory since the European entities have been adapting to the existing sustainability standards albeit implemented in a previously voluntary manner. Enterprises participating in the EU supply chain from third countries, on the other hand, will now become subject to requirements by European corporations to submit information on the sourcing of materials that would extend to numerous stages in the production network. It is highly likely that enterprises from less-developed countries that lack such information based on transparent business models will be disadvantaged from the burdensome application of the EU domestic regulations. In the medium and long-term, the EU regulations will work to realign their supply chains to give access to only third country enterprises that can afford to meet the sustainability standards, thus naturally raising the entry barriers into the EU market. Such de facto discrimination against foreign enterprises with low levels of capabilities in meeting sustainability standards would not be able to be justified if applied without consideration of other alternative measures with less trade restrictiveness. Furthermore, discriminatory treatment of products based on whether they have been sourced or processed in an environmental-friendly manner or based on respect of human rights, as the sustainability standards require, has not been recognized as being a legitimate policy measure under the current WTO jurisprudence. Discriminatory treatment of products based on different production 
methods cannot be justified under current WTO rules. Therefore, imposing more burden on imported products that have higher carbon concentration as compared to domestic like products that have lower carbon concentration can fall under 'less favorable treatment' under GATT Article III. Also, in response to the public or civil liabilities that corporations can be subject to as a result of non-compliance of the due diligence obligations, it is also likely that third-country enterprises at sub-levels of the production chain may face financial liabilities if any breach of the obligations is caused by their lack of implementation and capacity to prepare accordingly.

With regard to the Biden Administration's supply chain reform initiative which involves reshoring of US companies and promotion of manufacturing capacities with the participation of foreign companies, it may not necessarily be considered to be problematic in terms of adverse impact to trading partners. However, when combined with the 'Made in America' measures which requires procurement projects to give explicit preference to domestic suppliers through strengthened criteria and enforcement mechanisms, the resulting discriminatory impact on foreign suppliers can become problematic in terms of consistency with WTO rules. Whereas government procurement is an area basically excluded from the application of nondiscrimination rules, the combined effect of reshoring and 'Made in America' may be larger than expected, serving as a stronger incentive for US companies to come back to US territory. Ultimately, the role of foreign companies in the US supply chains will inevitably grow to become smaller, thus enabling US domestic manufacturers to squeeze out foreign manufacturers operating in US supply chains.

\subsection{WTO rules on subsidies}

The WTO rules on subsidies mainly prohibit subsidies that have adverse effects on the interests of trading partners whose industry may suffer from unfair competition with subsidized products. Therefore, subsidies that promote exports or substitute imports are, as a rule, prohibited. On the other hand, subsidies that are mainly used by governments for domestic legitimate policy purposes are not prohibited per se, but can be subject to discipline (become 'actionable' subsidies) if they are 'specific' (in contrast to being generally available) and cause adverse effects to the interests of other countries.

In order to be subject to the WTO subsidies disciplines, the policy measure at issue must, first of all, fall under the definition of a subsidy as provided in Article 1.1 of the Agreement on Subsidies and Countervailing Measures (SCM Agreement). For a measure to be a subsidy, it has to be a 'financial contribution' that has been granted by a 'government' or a 'public body', or any form of 'income or price support', and a 'benefit' has to be conferred by the financial contribution. Furthermore, there are four exhaustive types of 'financial contribution' listed in Article 1.1, namely: (1) direct transfer of funds (such as grants, loans, and equity infusions) or potential direct transfers of funds or liabilities (such as loan guarantees); (2) government revenue that is foregone or not collected; (3) provision or purchase by government of goods or services other than general infrastructure; (4) government payments to a funding mechanism through a private body. From this list, it is notable that the subsidization for 'general infrastructure' is explicitly exempted from the scope of disciplines, implying that it is not a violation of WTO rules when subsidization or government investment is made for 'general infrastructure'. The panel in EC-Large Civil Aircraft (WTO 2011a) defined that the term 'general infrastructure' refers to "infrastructure that is not provided to or for the advantage of only a single entity or limited group of entities, but rather is available to all or nearly all entities". However, the Appellate Body in EC - Large Civil Aircraft (WTO 2011b) also confirmed that the relevant transaction that falls under the disciplines is the "provision of goods or services in the form of infrastructure to Airbus, not the creation of that infrastructure". The Appellate Body further emphasized that "when a good or service has not been provided by a government, there can be a financial contribution cognizable under Article 1.1(a)(1)(iii)" (Van den Bossche and Zdouc 2013).

Under WTO rules, a 'benefit' has been conferred by a subsidy when the financial contribution has made "the recipient 'better off' than it would otherwise have been, absent that contribution". According to Article 14(a) of the SCM Agreement, a government provision of equity capital shall not be considered as conferring a 'benefit' when the investment decision can be regarded as consistent with the usual investment practice of private investors. It is notable that the current subsidies rules do not explicitly allow for public investments that are made based on strategic national decisions, which is an area where private investors cannot make, and therefore, may be inconsistent with the 'usual investment practice of private investors'. Also, a 'benefit' arises if the recipient has received the financial contribution on terms more favorable than those available to any recipient in the market. This requires the use of 'market benchmarks' which allow the analysis of the financial transaction at issue to be assessed against the terms that would result from undistorted markets. This analysis is especially hard when there is no commercial entity that is acting pursuant to commercial considerations to serve as a benchmark, which occurs in cases of 'market failure'. 
Lastly, the WTO rules on subsidies apply only when the financial contribution that confers a benefit is 'specific' to certain sectors or enterprises, and region. A subsidy that is widely available within an economy is presumed not to distort the allocation of resources within that economy (Van den Bossche and Zdouc 2013). However, large-scale public investment that is targeted at certain sectors for promotion of manufacturing capacities in those industries can be considered to be 'specific', and possibly a violation of WTO subsidies rules.

Based on these legal criteria for the assessment of compatibility of subsidization policy measures with WTO rules on subsidies, the large-scale investment projects under the AICA to modernize its economic infrastructure raises several issues can be subject to debate if raised in the context of dispute settlement. Since the public investments are aimed at promoting 'general infrastructure', there is a possibility that the measure may not fall under the list of 'financial contributions'. However, there is uncertainty over whether the AICA public investments can be considered to be mere 'provision' of existing general infrastructure, and not the 'creation' of general infrastructure. If it falls under the latter case, the general infrastructure exception may not apply anymore. Furthermore, since a significant large portion of the public investments would go into the selected industry sectors such as semiconductors, it is highly likely that they can be considered to be 'industry-specific', which is a clear violation of WTO rules.

In terms of 'benefit', the AICA legislation aims to promote strategically important sectors where private investment has not been made due to lack of efficiency and profitability based on market principles. However, the current WTO rules does not allow for large-scale public investment in areas where the private investors normally would not make investments based on market-based decisions. It is also unclear whether the legitimate policy objectives that are enshrined in the general exceptions clause in GATT Article XX apply as a legal basis for justification of measures that go against WTO subsidies rules. Therefore, public investments for the purposes of promoting environment protection, such as modernizing general infrastructure for the transition to a green economy may considered to be a violation of WTO rules. Public investments for promoting manufacturing capabilities in key strategic sectors, such as semiconductors, on the other hand, may be considered an outright violation of WTO subsidies rules. This is because the government is providing financial contribution in the form of direct transfer of funds to a specific industry, and conferring 'benefit' through the financial contribution since private investors have not made such investments based on market-based decisions. Furthermore, as a result of the increased competitiveness in the semiconductor industry, US domestic manufactures will export to global markets, raising the issue of export subsidies which are outrightly prohibited under WTO subsidies rules.

\subsection{General exceptions for legitimate policy objectives}

WTO rules allow for the promotion and protection of societal values and interests such as public health, consumer safety, the environment, and other legitimate public policy objectives. Trade liberalization, market access and non-discrimination rules that conflict with important societal values may be reconciled based on a set of rules that seek to balance between the conflicting interests. The 'general exceptions' in GATT Article XX provides ten legitimate policy objectives based on which measures that restrict trade liberalization and discriminatory treatment is allowed. Among these objectives, the relevant provisions that would apply to the supply chain reform initiatives of the US and EU can be expected to be Article XX (a), (b), and (g). These provisions allow Members to violate WTO obligations when 'necessary to protect public morals', 'necessary to protect human, animal or plant life or health', 'necessary to secure compliance with laws or regulations which are not inconsistent with the provisions of this Agreement', and 'relating to the conservation of exhaustible natural resources if such measures are made effective in conjunction with restrictions on domestic production or consumption'.

The sustainability standards that are used for due diligence requirements in EU supply chains place importance on the respect for labor rights as basic human rights. While there is currently no labor-related trade issue that has been raised within the WTO, the nexus between trade and labor has been recognized more frequently in FTAs, especially those involving the US and EU. The Korea-EU FTA incorporates labor related provisions in the Chapter on Trade and Sustainable Development (Chapter 13), which provides for the ratification of ILO (International Labor Organization) core treaties and the obligations of the FTA parties to labor and environmental protection. The US-Mexico-Canada Agreement (USMCA), the revised version of NAFTA (North American Free Trade Agreement), contains a separate Chapter on Labor (Chapter 23), and is considered to have the most advanced level of labor-related provisions so far. It includes provisions on the adoption and maintenance of ILO obligations, implementation of labor laws, forced labor, violence against workers, migrated workers, discrimination in office, etc. and a separate fast-track dispute settlement mechanism for labor-related disputes. Despite these developments, the protection of labor rights as a legitimate policy objective to allow for discrimination against foreign suppliers is quite a new concept, and there is currently no policy objective contained in GATT Article XX that directly relates to this policy measure. Instead, the closest 
policy objective may be the 'public morals' objective, under which the respondent may claim that respect for labor rights as a fundamental human rights issue is an important public morals issue as well. So far, the 'public morals' exception in GATT has been invoked in the WTO dispute case on China-Publications and Audiovisual Products (WTO 2010), in which China, as the respondent, was not successful in justifying its measures imposing regulations on foreign audiovisual products based on the need for protection of public morals. Whereas the panel recognized that there should be room for countries to define their own public morals and implement relevant measures based on unique systems and values, the measure at issue had to be sufficiently 'necessary' by not having other alternative policy measures that would attain the policy objective but with less traderestrictiveness.

Policy measures to protect the environment, such as EU's sustainability standards based on environment protection, may be justified under GATT Articles XX(b) and XX (g). In order to be successful in invoking Article XX(b), proving that the restrictive measure is 'necessary' to pursue the policy objective would be most critical for justification of the measure at issue. Providing scientific evidence and professional opinions that show that there was indeed a 'risk' to the life or health of humans or animal/plant would be the first step for justification. The 'necessity test' requires assessing the relative importance of the policy objective pursued by the measure at issue, the degree of contribution of the measure at issue to achieving the purported policy objective, and the level of trade restrictiveness of the measure at issue. The most important task in the necessity test would be to show that there is no other alternative measure with less trade-restrictiveness that helped to achieve the policy objective pursued by the measure at issue. Furthermore, after passing the necessity test, the respondent is required to show that the measure at issue was not used as a 'means of arbitrary or unjustifiable discrimination' between countries where the same conditions prevail, nor a 'disguised restriction on international trade' in accordance with the chapeau of GATT Article XX. To date, not many dispute cases have been successful in invoking GATT Article XX (b) for justifying the measure.

Invoking Article XX (g), on other hand, could be relatively easier, since there is no requirement to prove 'necessity' of the measure, but only that the measure 'relate to' the conservation of exhaustible natural resources. Policy measures to respond to the global climate change problem may fall under this provision since previous WTO judges have determined that 'exhaustible natural resources' may refer to both 'living and non-living' resources, implying that clean skies can fall under 'natural resources'. However, there is an additional condition attached to this provision which requires that the measure at issue should be 'made effective in conjunction with restrictions on domestic production or consumption'. Therefore, in order to invoke this provision, the measure at issue would have to be in the form of regulations that apply to both foreign and domestic entities alike. In the case of the EU due diligence obligations which are in the form of domestic regulations with extraterritorial application, the invocation of Article XX (g) may be able to provide justification for the trade restrictive impact. However, similar to the other exception provisions in Article XX, the requirements in the chapeau ('means of arbitrary or unjustifiable discrimination' or a 'disguised restriction on international trade') would have to be satisfied in order to be successful in justifying the measure.

\subsection{National security exceptions}

GATT Article XXI provides for exceptions relating to national and international security. Since the exception provisions were incorporated during times when national security took precedence over the benefits of trade, the provisions have inevitable structural and interpretative difficulties for applying them in today's world. However, there seems to be a general understanding that the security exceptions in Article XXI may be invoked when countries consider it necessary to restrict trade in order to protect strategic domestic production capabilities from import competition or other strategic competition issues (Van den Bossche and Zdouc 2013).

The security exceptions basically allow a Member to adopt or maintain certain measures which that Member 'considers it necessary' for the protection of its 'essential security interests'. There are three categories of measures that are allowed, of which two are related to nuclear weapons and trade in arms for military use. The last category of measure that is allowed is more pertinent to the world of today, which allows for 'measures taken in time of war or other emergency in international relations'. Due to the wording in the first part of the provision ('considers necessary'), there was heated debate over whether the security exceptions are 'justiciable' (whether the application of these exceptions can be reviewed by WTO panels and Appellate Body). However, the panel in Russia - Measures Concerning Traffic in Transit (WTO 2019b) dispute provided a significant ruling by determining that measures invoking the security exceptions in GATT are indeed subject to review by the judges of WTO Dispute Settlement Body. Furthermore, the panel in the dispute case ruled that 'essential security interests' are those 'interests relating to the quintessential functions of the state', and that the determination of the interests would be up to 
the 'particular situation and perceptions of the state', implying that it is basically the state that has the discretion to decide on its national security interests.

According to this logic, the US policy measures to realign its supply chains for key strategic sectors of its economy seem to

Table 2. Summary of assessment of policies related to supply chain resilience

\begin{tabular}{|c|c|}
\hline & WTO Rules \\
\hline Non-discrimination & $\begin{array}{l}\text { Policy measures that appear to be neutral } \\
\text { in its application based on nationality of } \\
\text { product or service can be a violation of } \\
\text { WTO non-discrimination rules if the } \\
\text { applied measure results in discrimination } \\
\text { against foreign product or service. }\end{array}$ \\
\hline
\end{tabular}

Subsidies Public investments can be subject to WTO disciplines if it confers a 'benefit' to the recipient, under which the investment decision does not follow the usual investment practice of private investors ('market benchmark').

WTO rules on subsidies apply when the financial contribution confers a benefit that is 'specific' to certain enterprises, sectors, or region.

General WTO rules allow for the protection of exceptions

National security exceptions societal values and interests, such as public health, consumer safety, environment, public morals, and other legitimate public policy objectives.

Policy measures to protect the environment may be justified under GATT Articles XX (b) and XX (g), but need to pass the 'necessity test' (for Article $\mathrm{XX}(\mathrm{b}))$ and/or that the measures are not 'means of arbitrary or unjustifiable discrimination' or a 'disguised restriction on trade'.

Security exceptions basically allow WTO Members to adopt or maintain certain measures which a Member 'considers it necessary' for the protection of its 'essential security interests', implying that it is basically the state that has the discretion to decide on its national security interests.

\section{Assessment}

EU's 'sustainability standards' that are used for determining environment or labor protection levels needed for entry into EU market are implicitly discriminatory

- Highly likely that firms from less-developed countries that lack transparent business models will be disadvantaged from burdensome application of EU domestic regulations.

- De facto discrimination against foreign firms with low levels of capabilities in meeting sustainability standards cannot be justified if applied without consideration of other alternative measures with less trade restrictiveness.

- Discriminatory treatment of products based on whether sourced or processed in environment-friendly manner or based on respect for human rights cannot be recognized as a legitimate policy measure under current WTO jurisprudence.

US supply chain reform initiative, when combined with 'Made in America' measures with strengthened criteria and enforcement mechanisms for providing explicit preference to domestic suppliers, can result in discriminatory impact on foreign suppliers and can be problematic in terms of consistency with WTO rules.

Current WTO subsidies rules do not explicitly allow for public investments that are made based on strategic national decisions, which is an area where private investors cannot make decisions, and thus such decisions may not be made pursuant to normal commercial considerations that are based on market conditions.

Large-scale investment projects under AICA to modernize economic infrastructure can be inconsistent with WTO subsidy rules if a significantly large portion of the public investments go into selected industry sectors ('industry-specific').

While the sustainability standards in the due diligence requirements for EU supply chains place importance on respect for labor rights as basic human rights, there is currently no policy objective contained in GATT Article XX that directly relates to the protection of labor rights as a legitimate policy objective to allow for discrimination against foreign suppliers.

EU's sustainability standards based on environment protection may be justified under Article XX (b), but needs to be proved that the restrictive measure is 'necessary' to pursue the policy objective, in particular, that there is no other alternative measure that is less traderestrictive for achieving the alleged policy objective.

While Article XX (g) may be more easily invoked (no 'necessity test' required), the measure still needs to be proved that they are not 'means of arbitrary or unjustifiable discrimination' or a 'disguised restriction on trade'.

US policy measures to align its supply chains for key strategic sectors of its economy seem to be justifiable in terms of its 'essential security interests', since the alleged US policy objective is to strengthen its national security, economic security and technology leadership. However, discretionary application of the security exceptions would leave the discriminatory impact of the 'Made in America' measures and large-scale public investments to promote its domestic industries at the sake of foreign suppliers and manufacturers undisciplined under the name of 'national security'. 
be justifiable in terms of its 'essential security interests', since the US Administration has continuously stressed that the supply chain initiatives were essential to its 'national security, economic security, and technology leadership'. However, if this were the case, the discriminatory impact of the 'Made in All of America' measures and large-scale public investments to promote its industrial competitiveness at the sake of foreign suppliers and manufacturers would all be excused, under the name of national security. Whether such broad application of the security exceptions, to the extent that the fundamental principles of trade liberalization, market access and non-discrimination is undermined, is what the initial negotiators had in mind is a question that calls for more serious debate considering the implications it would have on the international trade order. While it may be true that legitimate public policy objectives that support sustainability issues may deserve more room for justification considering the increasing societal needs and demands, competition issues related to strategic national decisions and international trade leadership would be an area that needs a more stringent approach and rigorous disciplines. Table 2 above provides a summary of the assessment of US and EU policies on supply chains.

\section{Conclusion}

While the COVID-19 pandemic has starkly revealed the vulnerabilities of the global supply chain and has ultimately led major economies to initiate reform of their supply chains, the approaches of the US and EU appear to be starkly different in terms of concentration vs. diversification of production sources. While the US attempts mainly to concentrate its production sources to domestic industries and thereby enhance its domestic manufacturing capacity, EU pursues more diversification of its production sources as response to vulnerabilities in its supply chain. However, both economies are similar in their attempt to increase the interventionist role of government in formulating higher criteria for participating in their markets or regional supply chains, and to enhance their domestic manufacturing capacity for increased competitiveness against foreign suppliers and manufacturers.

The US and EU approaches also seem to differ in terms of the explicitness of policy objective. Despite the apparent neutrality through application to both domestic and foreign suppliers in the EU case, the criteria for entering EU supply chains may actually be applied in a discriminatory way, especially against those economies which have lower standards of sustainability due to lower levels of economic development. On the other hand, the US approach explicitly gives preference to its domestic suppliers under its Buy America provisions, which can be considered to be outright discrimination against foreign suppliers. Furthermore, the US approach does not disguise its pursuit of industrial policy through large-scale investment incentives for modernizing its economic infrastructure that ultimately would serve to enhance its industrial competitiveness. While the subsidy rules in the current WTO regime do not prohibit the provision of financial incentives to build general infrastructure that lack specificity, it is highly likely that the investment projects would inevitably lead the US domestic manufacturers to become more competitive against foreign competitors.

Based on these observations, perhaps the EU approach to supply chain reform may be more consistent with the rules-based order, albeit the fact that the current international rules do not provide concrete criteria or guidance on where to draw the balancing line between trading rights and sustainability issues. Furthermore, the sustainability standards that are being applied for participating in the supply chains of major economies appear to have broadened their scope to include criteria with more social and democratic values, which have not been addressed in earnest to date due to their non-trade-related characteristics. However, the current shifts in paradigm in the world economic order to include societal, or more 'humanistic' values seem to be inevitable, judging from the policy directions and strategies that have been adopted by the major trading economies. According to Alan Wolffe, the former Deputy Director General of the WTO, "These times require a new humanism for trade policy. A broader lens than that of economic efficiency is needed. That should be a lesson of the pandemic (Wolffe 2021)." The future direction of the world economic order seems indeed to be undergoing an important change in paradigm, trying to incorporate 'sustainability' under the trade umbrella. However, it remains to be seen if these efforts will work for the international economy as a whole, or whether the global economy will be more starkly divided up into regional blocs with higher barriers of entry into the developed country markets.

\section{References}

Asian Development Bank, 2021. Asian Economic Integration Report 2021: Making Digital Platforms Work for Asia and the Pacific, Manila, Philippines.

Beghin, O., Vermulst, E., 2021. New EU Rules on Supply Chain Due Diligence: A Net Cast Too Wide? Regulating for 
Globalization. Kluwer Regulating for Globalization blog. Available at: http://regulatingforglobalization.com/2021/04/ 15/new-eu-rules-on-supply-chain-due-diligence-a-net-cast-too-wide/

Bergsen, P., 2021. The EU's Unsustainable China Strategy. Research Paper: European Programme. Chatham House, London, UK.

Council of the European Union, 2020. Council Conclusions on Human Rights and Decent Work in Global Supply Chains. European Union, Brussels, Belgium.

Council of the European Union, 2019. An EU Industrial Policy Strategy: A Vision for 2030 - Council Conclusions (adopted on 27/05/2019). European Union, Brussels, Belgium.

CSIS, 2021. Experts React: Assessing the White House 100-Day Supply Chain Review. Center for Strategic and International Studies. Available at: https://www.csis.org/analysis/experts-react-assessing-white-house-100-day-supply-chain-review

European Commission, 2019. EU-China: A Strategic Outlook. European Union, Brussels, Belgium.

European Commission, 2020. Communication from the Commission to the European Parliament, the European Council, the Council, the European Economic and Social Committee and the Committee of the Regions: A New Industrial Strategy for Europe (COM/2020/102 final). European Union, Brussels, Belgium.

European Commission, 2021. Annex to the Communication from the Commission to the European Parliament, the Council, the European Economic and Social Committee and the Committee of the Regions, Trade Policy Review - An Open, Sustainable and Assertive Trade Policy, COM(2021) 66 Final. European Union, Brussels, Belgium.

European Parliament, 2020. Report on Sustainable Corporate Governance (2020/2137(INI)). Committee on Legal Affairs. European Union, Brussels, Belgium.

European Parliament, 2021. Corporate Due Diligence and Corporate Accountability. European Parliament Resolution of 10 March 2021 with Recommendations to the Commission on Corporate Due Diligence and Corporate Accountability (2020/2129(INL)). European Union, Brussels, Belgium.

Gölgeci, I., Yildiz, H. E., Andersson, U., 2020. The rising tensions between efficiency and resilience in global value chains in the post-COVID-19 world. Transnational Corporations Journal 27, 127-141.

Schneider-Petsinger, M., 2021. US and European Strategies for Resilient Supply Chains: Balancing Globalization and Sovereignty. US and the Americas Programme Research Paper. Chatham House, London, UK.

The Economist, 2021. North American Supply Chains: Will Reshoring Actually Happen? The Economist Intelligence Unit, London, UK.

The White House, 2021. Building resilient supply chains, revitalizing American manufacturing, and fostering broad-based growth. 100-Day reviews under executive order 14017. Available at: https://www.whitehouse.gov/wp-content/uploads/ 2021/06/100-day-supply-chain-review-report.pdf

Van den Bossche, P., Zdouc, W., 2013. The Law and Policy of the World Trade Organization: Text, Cases and Materials. Cambridge University Press, New York, US.

Wolffe, A. W., 2021. The world economic order - Building the WTO back better. Available at: https://www.piie.com/ commentary/speeches-papers/world-economic-order-building-wto-back-better

WTO, 2010. Appellate Body Report, China - Measures Affecting Trading Rights and Distribution Services for Certain Publications and Audiovisual Entertainment Products, WT/DS363/AB/R (adopted 19 January 2010).

WTO, 2011a. Panel Report, European Communities and Certain Member States - Measures Affecting Trade in Large Civil Aircraft, WT/DS316/R (adopted 1 June 2011).

WTO, 2011b. Appellate Body Report, European Communities and Certain Member States - Measures Affecting Trade in Large Civil Aircraft, WT/DS316/AB/R (adopted 1 June 2011).

WTO, 2019a. Global Value Chain Development Report 2019: Technological Innovation, Supply Chain Trade, and Workers in a Globalized World. World Trade Organization, Geneva, Switzerland.

WTO, 2019b. Panel Report, Russia - Measures Concerning Traffic in Transit, WT/DS512/R (adopted 26 April 2019). 